\title{
Belanja Online di Masa Pandemi Covid-19: Studi Kasus Ibu-ibu Rumah Tangga di Makassar
}

\author{
Andi Maghfirah Juniar ${ }^{1}$, Jusrianti ${ }^{2}$ \\ 1,2 Univeritas Hasanuddin \\ 1egamaghfirah4@gmail.com \\ 2jusriantiucy@gmail.com
}

\begin{abstract}
In early 2020 the world was shocked by the outbreak of a new type of virus (SARS-CoV-2) known as Corona virus disease 2019 (abbreviated as Covid-19), whose first case was discovered at the end of December 2019 in Wuhan, China. The outbreak of the Covid-19 was known to have entered Indonesia in mid-March 2020, resulting in Indonesia entering the Disaster Emergency Period. The entry of Covid-19 in Indonesia prompted the government to adopt a Large-Scale Social Restriction (PSBB) policy to stop the wider spread of Covid-19. With this policy, people's activities outside the home are limited, and more people's activities are diverted at home, including shopping online through applications. In this context, the ease of shopping online may resulted in consumptive behavior when one can't control him/herself.

This research was conducted between September and November 2020 in the city of Makassar City. Makassar was chosen because based on online observations, many housewives in the Makassar area tend to behave consumptively during the outbreak Covid-19. This can be seen from the habit of shopping online which is supported by technology and the ease of accessing online applications. Data was collected through indepth interviews and observation. Those who participated in this study were ten housewives who had a history of routine shopping online using a shopping application.
\end{abstract}

The study indicates that the Covid-19 pandemi has limited people's mobility, one of which is social restriction policies issued by the government which has changed many aspect of human life, including their shopping method. This shopping method has changed from direct shopping through which human interaction occurs to more often online shopping, using online shopping applications. Housewives perceive online shopping in various ways, from relating it to the simplicity of shopping; transaction process using advanced technology; to shopping by using online shopping applications. The reasons why online shopping is in favour among housewives during the Covid-19 pandemi are the availability of a variety of offered goods, its convenience and practicality, its safety and comfort, and its discount offers. During the Covid-19 pandemi, this way of shopping intensifies. In addition to its advantages, online shopping also has weaknesses, namely the discrepancy between the appearance of the goods ordered and the reality of the goods received; the purchased goods cannot be received directly because it requires delivery time; vulnerability to damage to goods in the shipping process, and vulnerability to fraud. Therefore, consumers must consider the needs and desires in order to be able to control themselves in shopping because not all the desired items are needed items. In addition, fraud is vulnerable in online shopping. Thus consumers not only have to question the goods to be purchased in as much detail as 
possible; selective in choosing online stores; but also one must identify the track record of intended online store.

Keywords: Covid-19, housewives, online shopping, online store, and social media.

\section{Pendahuluan}

Di awal tahun 2020 dunia digemparkan dengan merebaknya virus baru (SARS-CoV-2) atau corona virus disease (Covid) yang pertama kali ditemukan di Wuhan, Cina pada akhir tahun 2019, dan populer dengan istilah Covid-19. Virus ini kemudian menyebar dengan sangat cepat ke hampir semua negara dalam waktu singkat, termasuk Indonesia (Warta Ekonomi 2020). Wabah pandemi Covid-19 diketahui masuk ke Indonesia pada pertengahan bulan Maret 2020. Bahkan di beberapa provinsi memiliki angka kasus Covid-19 tertinggi, salah satunya yaitu Sulawesi Selatan. Data per tanggal 29 Mei 2021, Sulawesi Selatan berada pada peringkat enam dengan jumlah kasus terkonfirmasi sebanyak 62.024 setelah DKI Jakarta (425.829), Jawa Barat (308.409), Jawa Tengah (195.786), Jawa Timur (153.596), dan Kalimantan Timur (71.092 kasus terkonfirmasi). ${ }^{1}$

Merebaknya kasus Covid-19 di Indonesia membuat Menteri Kesehatan melalui Surat Edaran Nomor HK.02.01/MENKES/332/2020 Tahun 2020 tentang Pembatasan Sosial Berskala Besar (PSBB) sebagaimana tertuang dalam Peraturan Pemerintah Nomor 21 Tahun 2020 tentang Pembatasan Sosial Berskala Besar Dalam Rangka Percepatan Penanganan Corona Virus Disease 2019 (Covid-19) dan Peraturan Menteri Kesehatan Nomor 9 Tahun 2020 tentang Pedoman Pembatasan Sosial Berskala Besar

\footnotetext{
${ }^{1}$ http://www.hukumonline.com/pusatdata, diakses tanggal 27 September 2020.
}

Dalam Rangka Percepatan Penanganan Corona Virus Disease 2019 (Covid-19). ${ }^{2}$

Dengan dikeluarkannya surat edaran ini, maka kegiatan-kegiatan yang biasa dilakukan di luar rumah lebih banyak dilakukan di rumah, termasuk belajar dari rumah, bekerja dari rumah dan berbelanja dari rumah dengan penggunaan aplikasi belanja online. Dalam berbelanja online, kegiatan berbelanja online tidak hanya dilakukan pada aplikasi Lazada dan Shopee saja, namun, ini juga dapat dilakukan melalui media sosial, seperti Facebook.

Menurut Harahap dan Amanah (2018:195), belanja online atau e-commerce adalah sebuah proses transaksi yang dilakukan melalui media atau perantara, yaitu berupa situs-situs jual beli online ataupun jejaring sosial yang menyediakan barang atau jasa yang diperjualbelikan. Kini belanja online, meskipun bukan hal baru, sejak mewabahnya Covid-19 telah semakin intensif digunakan orang. Jumlah pelanggan e-commerce mengalami peningkatan hingga 38,3 persen selama masa pandemi Covid-19. Data tersebut bersesuaian dengan catatan yang dilaporkan Exabytes, perusahaan penyedia layanan hosting dIndonesia. Di satu sisi, situasi ekonomi mengalami kemerosotan. Di sisi lain, perkembangan teknologi melahirkan peluang baru, khususnya di bidang e-commerce. Pertumbuhan e-commerce yang naik pesat disebabkan oleh perubahan perilaku konsumen yang memenuhi kebutuhan sehari-hari dengan

\footnotetext{
2 https://www.antaranews.com/covid-19, diakses tanggal 29 Mei 2021.
} 
berbelanja secara online, terutama dimasa PSBB. $^{3}$

Pandemi Covid-19 membuat semua kegiatan yang dilakukan di luar rumah dibatasi, baik itu kegiatan belajar-mengajar, beribadah, maupun bekerja. Hal ini juga memengaruhi aktivitas-aktivitas lainnya, termasuk kegiatan berbelanja kebutuhan sehari-hari, di antaranya kebutuhan pangan, sehingga terjadi peningkatan dalam belanja online itu sendiri.

Proses berbelanja online tersebut dapat dilakukan dengan cara memesan barang yang diinginkan melalui vendor atau produsen serta reseller dengan menggunakan teknologi internet melalui ponsel pintar (smartphone). Selanjutnya, pembayaran dilakukan dengan cara mentransfer via bank, e-bank, ataupun membayar di tempat saat barang diantarkan, yang diistilahkan sebagai Cash on Delivery (COD). Dengan kemudahan-kemudahan yang dimilikinya, hal ini dapat membuat orang menjadi konsumtif karena mereka berbelanja berdasarkan pada keinginan ketimbang kebutuhan (Astuti 2013:80), dan tindakan ini jika tidak dapat mengontrol diri, maka akan menyebabkan seseorang berprilaku konsumtif. Menurut Setiaji (1995), perilaku konsumtif adalah kecenderungan seseorang berperilaku secara berlebihan dalam membeli sesuatu atau membeli secara tidak terencana, seringkali tak terkendali dan menjadi tidak rasional.

Pada dasarnya, perilaku konsumen secara umum dibagi atas dua, yaitu perilaku konsumen yang bersifat rasional dan irrasional. Yang pertama merujuk pada perilaku konsumen dalam pembelian suatu barang dan jasa yang mengedepankan aspek-aspek seperti kebutuhan mendesak, kebutuhan utama/primer, serta daya guna produk itu sendiri terhadap pembelinya.

\footnotetext{
${ }^{3}$ https://irto.id/jumlah-pelanggan-e-commercetercatat-meningkat-383-selama-pandemi-f1eP, diakses tanggal 9 Desember 2020.
}

Yang kedua merujuk pada perilaku konsumen yang mudah terbujuk oleh iming-iming diskon atau marketing dari suatu produk tanpa mengedepankan aspek kebutuhan atau kegunaan (Sumarni dkk. 2020:7).

Ibu rumah tangga merupakan salah satu kelompok shopper personas atau kelompok pebelanja yang memiliki perilaku unik dan dianggap memiliki porsi yang signifikan terhadap total konsumen, khususnya di Indonesia. Insight terbaru Snapcart bertajuk "Housewives Persona Deep Dive" merinci kebiasaan berbelanja ibu rumah tangga mengenai kategori produk yang sering dibeli seperti pakaian, assesoris dan skincare. Pihak Snapcart dalam rilis resminya mengungkapkan, bahwa data yang didasarkan pada analisa 505.000 struk belanja periode antara bulan Januari 2016 dan Februari 2017, salah satu temuannya menunjukkan bahwa ketika ibu rumah tangga berbelanja di ritel modern, 55,1\% dari mereka melakukannya di mini market, $30,46 \%$ di supermarket, dan $12,78 \%$ di hypermarket. ${ }^{4}$

Studi-studi tentang perilaku konsumtif telah banyak dilakukan, terutama terkait dengan mahasiswa (Thohiroh 2015; Rusli dkk. 1998; Aeni 2019; Anggreini dan Maryanti 2014). Studi Thohiroh (2015) tentang perilaku konsumtif di kalangan mahasiswi menunjukkan bahwa perilaku berbelanja konsumtif telah menjadi gaya hidup mahasiswi dan mereka berbelanja hanya karena kesenangan, pembelian impulsif (suatu pembelian yang secara tiba-tiba tanpa adanya niat sebelum belanja). Mereka bahkan rela menjual barangbarang berharga, seperti assesoris emas, kamera, handphone dan merelakan diri makan

\footnotetext{
${ }^{4}$ https://femaleradio.co.id/female-info/femalelifestyle/6284-infografis-kebiasaan-belanja-iburumah-tangga, diakses tanggal 12 April 2021.
} 
seadanya hanya untuk membeli barang yang diinginkan, terutama pakaian demi menunjang penampilan mereka.

Ini berbeda dengan berbelanja di kalangan ibu-ibu rumah tangga berdasarkan kajian Rusli dkk. (1998) yang menggambarkan bahwa ibu-ibu rumah tangga yang berbelanja pada pasar-pasar tradisional yang umumnya berbelanja berdasarkan kebutuhan dan manfaat suatu barang yang dibeli, dan kualitas belum menjadi pertimbangan utama. Yang memengaruhi perilaku belanja tersebut terutama nilai-nilai sosial budaya terkait berbelanja yang menganggap bahwa berbelanja yang terbaik adalah jika berbelanja dengan pertimbangan utama karena kebutuhan dan manfaat bukan karena hasrat dan keinginan semata. Artikel ini lebih terfokus pada ibu-ibu rumah tangga yang berbelanja secara online. Meskipun berbelanja secara online bukan hal baru di antara ibu-ibu rumah tangga, cara berbelanja seperti ini semakin intensif di masa pandemi Covid-19.

Pembahasan dalam artikel ini dibagi atas tiga bagian. Bagian pertama membahas tentang persepsi ibu rumah tangga tentang belanja online. Bagian kedua, pembahasan difokuskan pada alasan ibu rumah tangga memilih belanja secara online. Bagian ketiga diskusi dititikberatkan pada kelemahan dalam berbelanja secara online.

\section{Metode Penelitian}

Penelitian ini menggunakan pendekatan kualitatif dan dilakukan antara bulan September dan November 2020 di Kota Makassar. Lokasi ini dipilih karena berdasarkan dari hasil pengamatan secara langsung terhadap ibu-ibu rumah tangga di kota Makassar yang sering menggunakan aplikasi belanja online, seperti Shopee dan Lazada. Selain kedua aplikasi belanja online tersebut, berbelanja di media sosial seperti Facebook juga seringkali menjadi salah satu media alternatif dalam berbelanja secara online.

Informan dalam penelitian ini adalah ibu-ibu rumah tangga yang sering melakukan kegiatan berbelanja secara online, dan mereka semakin intensif berbelanja online selama pandemi Covid-19. Mereka berjumlah sepuluh orang yang bervariasi berdasarkan umur (antara 23 dan 47 tahun) dan mereka berasal dari status sosial yang relatif sama (kelas menengah), sebagaimana dijabarkan pada Tabel 1 di bawah ini.

\begin{tabular}{|l|c|c|c|}
\hline \multicolumn{4}{|c|}{ Tabel 1. Informan Peneliti } \\
\hline No. & Nama & Usia (Tahun) & Status Sosial \\
\hline 1. & Rina & 23 & Kelas Menengah \\
\hline 2 & Lisna & 25 & Kelas Menengah \\
\hline 3. & Tyas & 26 & Kelas Menengah \\
\hline 4. & Nindi & 29 & Kelas Menengah \\
\hline 5. & Zalsa & 33 & Kelas Menengah \\
\hline 6. & Lilis & 34 & Kelas Menengah \\
\hline 7. & Uni & 39 & Kelas Menengah \\
\hline 8. & Sardiana Ana & 42 & Kelas Menengah \\
\hline 9. & Anti & 43 & Kelas Menengah \\
\hline 10. & A. Chandra & 47 & Kelas Menengah \\
\hline
\end{tabular}


Pengumpulan data dilakukan melalui
teknik wawancara mendalam (in-depth interview), dan pengamatan (observation). Wawancara dilakukan secara offline dengan mematuhi protokol kesehatan dan secara online, tergantung kesepakatan dengan prospektif informan. Menurut Schimier (dalam Ismail, dkk. 2019:95), metode connective ethnography memungkinkan peneliti untuk melakukan wawancara secara online tanpa harus melibatkan interaksi secara fisik (face to face). Topik-topik wawancara meliputi persepsi IRT tentang belanja online; alasan berbelanja online; kelemahan dalam berbelanja online. Observasi dilakukan dengan mengamati aktivitas ibu rumah tangga yang sedang melakukan belanja online, seperti pencarian barang hingga memutuskan untuk memberlinya, pemesanan barang, hingga pembayaran.

Analisis dimulai dengan mengumpulkan semua data yang diperoleh melalui teknik wawancara mendalam dan observasi. Data wawancara ditranskripkan dan disandingkan dengan catatan observasi. Ini kemudian dilanjutkan dengan mengelompokkan data berdasarkan temuan-temuan sesuai dengan tema-tema yang muncul, seperti bagaimana pandangan ibu rumah tangga tentang belanja online, alasan berbelanja online, intensitas belanja online dan kelemahan dalam berbelanja secara online.

Dalam penelitian ini, kesediaan informan diperoleh melalui chat personal pada aplikasi Whatsapp dan Facebook dengan terlebih dahulu menjelaskan identitas peneliti, topik penelitian, maksud dan tujuan penelitian, serta topik-topik pertanyaan yang akan dipertanyakan. Jika mereka menyetujui untuk berpartisipasi dalam penelitian ini, maka mereka dimintai izinnya untuk direkam selama wawancara berlangsung. Dalam penelitian ini perekrutan informan dilakukan dengan teknik purposive sampling. Dimana peneliti menentukan kriteria dalam mencari informan, ibu rumah tangga yang menetap di kota Makassar, menggunakan aplikasi belanja online, seperti Lazada dan Shopee, karena keduanya merupakan dua toko online yang terpopuler, termasuk di kalangan ibu-ibu rumah tangga. Selain Informan dalam penelitian ini menggunakan nama asli dan tidak disamarkan sesuai dengan kesepakatan pada saat sebelum wawancara dilakukan.

\section{Persepsi IRT Tentang Belanja Online}

Belanja online adalah sebuah proses transaksi yang dilakukan melalui media atau perantara, yaitu berupa situs-situs jual beli online atau jejaring sosial yang menyediakan barang atau jasa yang diperjualbelikan. Belanja online juga dapat diartikan sebagai keinginan konsumen untuk membelanjakan uangnya demi mendapatkan sesuatu yang diinginkan di toko online (Harahap dan Amanah 2018:195).

Menurut Liang dan Lai (dalam Harahap dan Amanah 2018:196), perilaku pembelian secara online adalah proses membeli produk atau jasa melalui media internet. Proses pembelian secara online memiliki langkah yang berbeda dari berbelanja secara langsung (offline). Kekhasan dari proses membeli melalui media internet adalah ketika konsumen menggunakan internet dan mencari informasi yang berkaitan dengan barang atau jasa yang dibutuhkan. Barang-barang yang dibeli secara tidak langsung, tapi dilakukan melalui gadget, tanpa interaksi secara fisik. Di Indonesia, berbelanja secara online bukan hal baru, tapi sejak pandemi Covid-19, aktivitas tersebut semakin intensif dilakukan, termasuk oleh ibu- 
ibu rumah tangga. Bagaimana persepsi ibu-ibu rumah tangga tentang belanja online?

Umumnya mereka mempersepsikan belanja online dalam hubungannya dengan simplisitas jual belinya, sebagaimana yang dikemukakan oleh Nindi (29 tahun), bahwa belanja online merupakan suatu bentuk perdagangan eletronik yang banyak menyimpelkan orang dalam berbelanja. Bagi Nindi, belanja online merupakan pilihan terbaik untuk mencari produk yang ingin dibeli tanpa harus keluar rumah, terutama di masa pandemi Covid-19, dimana orang tidak saja membatasi diri untuk berinteraksi secara langsung, tapi juga menghindari kerumunan. la mengekspresikannya dengan sebuah frasa: "Selagi bisa di rumah aja, ngapain harus capekcapek keluar". Nindi merupakan pelanggan setia dari salah satu aplikasi belanja online (Sophee) nomor satu di Indonesia.

Ada pula yang mempersepsikan belanja online dalam kaitan dengan prosesnya dalam bertransaksi yang dikaitkan dengan kemajuan teknologi. Uni (39 tahun), misalnya, mengemukakan, bahwa kemajuan teknologi memudahkan orang untuk berbelanja secara online. Menurutnya, belanja online merupakan proses transaksi berupa jual beli yang dilakukan tanpa bertatap muka.

Rina (23 tahun) mempersepsikan belanja online sebagai cara berbelanja dengan menggunakan aplikasi belanja (seperti Shoopee, dII.). Sebelum Covid-19 mewabah, Rina (23 tahun) tidak terbiasa berbelanja secara online, ia biasanya berbelanja di toko-toko besar yang tidak jauh dari rumahnya. Namun, karena pandemi Covid-19 yang membatasi mobilitas masyarakat dengan kebijakan PSBB yang dikeluarkan pemerintah, ia beralih berbelanja secara online. Hampir semua produk yang dibutuhkannya dibeli secara online. Hingga saat ini, meskipun situasi semakin kondusif, ia tetap menggunakan aplikasi belanja online untuk berbelanja.

\section{Alasan Berbelanja Online}

Berbagai alasan dikemukakan oleh ibu rumah tangga di kota Makassar dalam kaitan dengan kenapa berbelanja secara online menjadi pilihan mereka di masa pandemi Covid-19 ini. Alasanalasan tersebut mencakup ketersediaan beraneka ragam barang, kemudahan dan kepraktisan, keamanan dan kenyamanan, dan tawaran diskon.

\section{Ketersediaan Beraneka Ragam Barang}

Ketersediaan beraneka ragam barang merupakan daya tarik tersendiri bagi konsumen untuk berbelanja secara online apalagi di tengah pandemi Covid-19, ketika keluar rumah untuk berbelanja berupaya dihindari. Pada dasarnya, belanja online-sebagaimana belanja secara offline-juga menyediakan berbagai macam produk, baik kebutuhan sandang maupun pangan, dari fashion, skincare, perawatan badan, kosmetik, assesori, makanan dan minuman, dll.

Tersedianya beraneka ragam barang pada aplikasi belanja online (seperti Shopee dan Lazada) dan media sosial (seperti Facebook) yang dijadikan sebagai wadah memosting barang dan produk yang sangat diminati juga menjadi salah satu daya tarik bagi para konsumen untuk berbelanja secara online. Selain itu, jenis barang, pilihan merek, ukuran, warna, model hampir semuanya tersedia di situs belanja online. Misalnya, ketika seseorang mencari suatu barang seperti baju batik, namun tidak menemukan barang yang sesuai dengan apa yang dicarinya, maka ia dapat mencari kebutuhan di toko online lainnya, tanpa harus mengunjungi tokonya langsung secara fisik. Apalagi di masa pandemi Covid-19 banyak penjual yang membuat akun pada aplikasi 
belanja online (seperti Shopee dan Lazada) untuk menawarkan barang-barang yang dijual, sehingga pilihan semakin banyak.

Ninda (29 tahun) mengungkapkan bahwa setiap mencari produk baru ia tidak perlu kemana-mana, tinggal tekan tombol handphone-nya, maka barang yang ingin dibelinya dapat langsung dipesan. Ini berbeda dari berbelanja dengan cara transaksi langsung (offline), "ada uang ada barang". Oleh karenanya, jika Nindya mencari barang yang akan segera digunakan, seperti kebutuhan fashion-nya, maka ia memilih untuk bertransaksi secara offline melalui toko yang menjual barang yang ditargetkannya. Namun, jika ia tidak kepepet untuk menggunakannya, maka ia tinggal memesannya dan jika barang tersedia, maka barang tersebut dapat langsung dikirimkan padanya. Berapa lama barang sampai kepada orang yang dituju tergantung kelas pengirimannya, apakah ekspres, atau regular, dll. Sejak pandemi Covid-19, Ninda memang lebih memilih belanja online ketimbang datang langsung ke mall demi menjaga dirinya dari penularan Covid-19.

Di masa pandemi Covid-19 ini, belanja online, menurut Lisna (25 Tahun) memang sangat membantu karena orang tidak berinteraksi langsung ketika berbelanja, tinggal mencari apa yang akan dibelinya, meng-kliknya dan barang tersebut akan muncul di layar, membayarnya secara online, meskipun ia harus menunggu pengantaran atau pengirimannya. Toko-toko online terbuka sepanjang waktu, selalu dapat diakses, dan orang dapat berbelanja kapan saja, serta tanpa harus keluar rumah. Ini sangat membantu ibu-ibu rumah tangga dalam menjalankan aktivitas sehariharinya, tanpa harus meninggalkan rumah.

\section{Kemudahan dan Kepraktisan}

Alasan lain kenapa berbelanja online adalah karena kemudahan dan kepraktisan yang mereka peroleh. Kemudahan dan kepraktisan tersebut yang membuat para ibu rumah tangga menjadi lebih mudah dalam berbelanja. Menurut Anti (43 tahun), belanja online sangatlah mudah dan praktis karena hanya dengan bermodalkan kuota untuk membuka aplikasi belanja online (seperti Shopee, Lazada, dII.). la lalu dapat memilih barang apa saja yang ingin dibeli dan memasukkannya ke dalam keranjang, membayarnya, maka barang sudah terbeli, tinggal menunggu pengantaran atau pengirimannya.

Ini sangat berbeda jika harus membeli barang secara langsung di toko/mall. Kemudahan dan kepraktisannya dapat dilihat dari segi waktu dan untuk mengaksesnya bisa kapan saja (pagi, siang, ataupun malam), sehingga barang dapat dilihat kapan saja, dapat dilakukan dimana saja. Namun, di masa pandemi Covid-19, kebanyakan pemesanan dilakukan dari rumah.

$\begin{array}{lll} & \text { Menurut Ninda (29 tahun), bahwa } \\ \text { dirinya merasa lebih mudah ketika } & \text { mengunakan aplikasi belanja online }\end{array}$
dibandingkan harus ke mall atau toko hanya untuk mencari, misalnya, pakaian, sepatu, dll. Hanya dengan menggunakan smartphone dan mengunduh aplikasi Shopee semua proses jual beli dapat dilakukan dengan mudah. Di masa pandemi Covid-19, ini secara tidak langsung membantu kebijakan pemerintah untuk lebih banyak di rumah ("di rumah aja") ketimbang beraktivitas di luar rumah.

Pernyataan lain diungkapkan oleh Sardiana (42 tahun), bahwa belanja online sangat memberikan kemudahan secara pribadi karena ia dapat memeroleh apa yang dibutuhkan dan diinginkannya tanpa harus keluar rumah. Aktivitas berbelanjanya tidak saja 
menjadi mudah, tapi juga praktis, terutama karena ia memiliki anak bayi yang cukup merepotkan jika harus keluar untuk berbelanja, apalagi di masa pandemi Covid-19.

\section{Keamanan dan Kenyamanan}

Keamanan dan kenyamanan dalam berbelanja adalah aspek lainnya yang menjadi pertimbangan dalam berbelanja secara online.
Anti (43 Tahun), misalnya, menyatakan bahwa belanja online memang tempat belanja yang aman, dan nyaman. Gambar 1 menunjukkan bagaimana proses pengiriman pembelian hingga tiba di tangan konsumen, sehingga konsumen tidak perlu takut akan penipuan karena semuanya terpantau oleh aplikasi, dan telah digunakan oleh banyak pengguna di Indonesia.

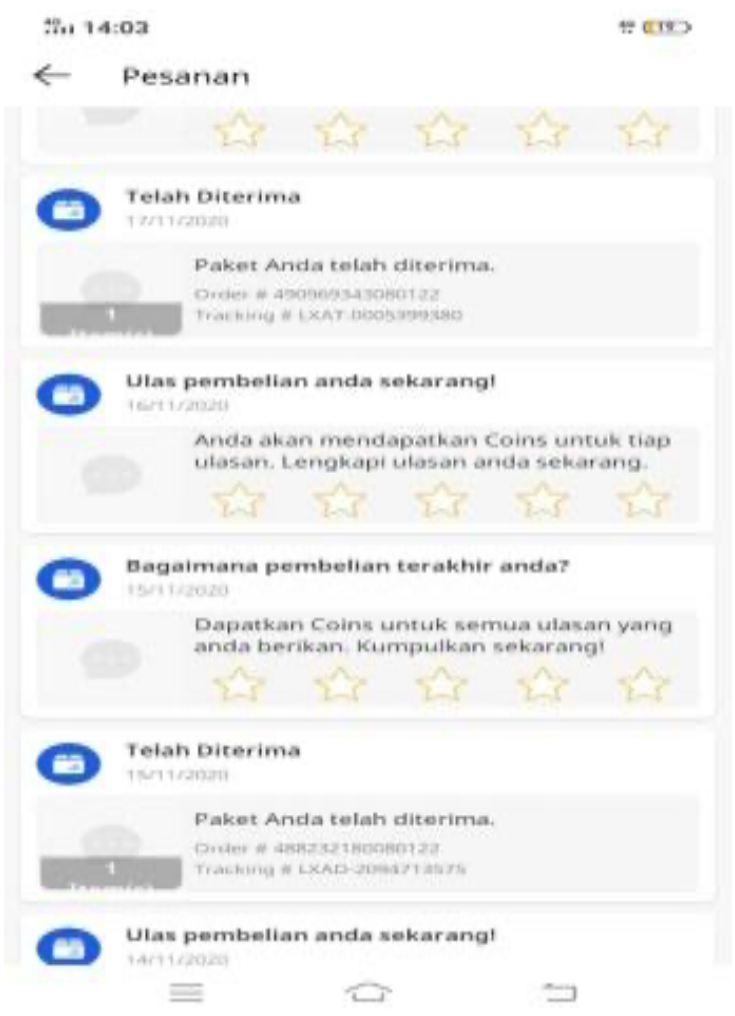

Gambar 1. Status Pengiriman

Dalam kaitan dengan pandemi Covid-19,

Anti menjelaskan pengalamannya ketika berbelanja secara online. Menurut pengirimnya, barang yang dipesan telah disemprot desinfektan terlebih dahulu sebelum dilakukan pengiriman. Anti sendiri, sebagai penerima paket, juga menyemprot paket tersebut dengan cairan desinfektan sebelum membukanya. Kemudian iapun menggunakan hand sanitizer setelahnya. Dengan menjalankan protokol tersebut Anti paling tidak merasa aman dan nyaman jika berbelanja secara online.

\section{Tawaran Diskon}

Minat beli seringkali digunakan untuk menganalisa dan melihat perilaku konsumen sebelum melakukan tindakan dengan membeli produk atau jasa. Menurut Assael (1998) minat pembelian merupakan perilaku yang muncul sebagai respon terhadap obyek yang menunjukkan keinginan pelanggan untuk 
melakukan pembelian. Selain itu, pembeli juga mempertimbangkan beberapa hal saat melakukan transaksi, di antaranya potongan harga (discounted price). Diskon merupakan potongan harga yang diberikan untuk menarik minat beli konsumen dan ini juga menjadi salah satu daya tarik orang berbelanja secara online.

Ketika menggunakan jasa aplikasi belanja online, terkadang konsumen tidak memerhatikan dengan teliti toko online yang dikunjungi dan tidak menyimak review dari pembeli-pembeli sebelumnya. Ini penting karena itu berkaitan dengan validitas dan professional tokonya, serta berassosiasi dengan rekam jejak penjualannya.

Menurut Kotler (2003) ada empat bentuk diskon. Pertama, diskon kuantitas, merupakan potongan harga yang diberikan untuk menstimulasi konsumen agar membeli dalam jumlah yang lebih banyak, sehingga meningkatkan volume penjualan secara keseluruhan. Kedua, diskon musiman, merupakan potongan harga yang diberikan hanya pada masa-masa tertentu saja. Ini digunakan untuk mendorong konsumen agar membeli barang-barang yang sebenarnya baru akan dibutuhkan beberapa waktu mendatang. Dengan demikian, diskon musiman memberikan pengaruh yang cukup besar terhadap pola pembelian konsumen, sehingga fungsi persediaan atau penyimpanan bergeser ke tangan konsumen. Ketiga, diskon tunai (cash discount), merupakan potongan harga yang diberikan kepada pembeli yang membayar secara tunai barang-barang yang dibelinya atau membayarnya dalam jangka waktu tertentu sesuai dengan perjanjian transaksi. Keempat, trade (functional) discount, yaitu potongan harga yang diberikan oleh produsen kepada penyalur (distributor) yang terlibat dalam pendistribusian barang dan pelaksanaan fungsi- fungsi tertentu, seperti penjualan, penyimpanan dan record keeping.

Meskipun ada berbagai alasan kenapa orang membeli barang, namun diskon berpengaruh sangat signifikan terhadap perilaku berbelanja ibu-ibu rumah tangga yang berpartisipasi dalam penelitian ini. Jika merujuk pada keempat bentuk diskon di atas, maka menurut Rina (23 tahun) daya belinya dipengaruhi dan didorong oleh diskon kuantitas, yang biasanya diistilah sebagai belanja grosir. Semakin banyak barang yang dibeli, semakin banyak diskon yang diperoleh, sehingga ini menjadi daya tarik tersendiri untuk membuatnya membeli barang dalam jumlah banyak dan ini memang menjadi target penjual.

Ini berbeda dari Andi Chandra (47 tahun), Uni (39 tahun), dan Lilis (34 tahun) yang cenderung berbelanja ketika sedang ada diskon yang diberikan oleh aplikasi belanja online di waktu-waktu tertentu (diskon musiman) dan ini sangat menggiurkan, sehingga membuat mereka makin bersemangat untuk berbelanja. Kadang diskonnya dalam bentuk diskon harga barang, dan kadang juga berupa diskon berupa bebas ongkos kirim (ongkir). Diskon membuat orang yang awalnya hanya browsing dan tidak bermaksud berbelanja, akhirnya berbelanja karena ketertarikan akan diskon tersebut. Dalam konteks ini, diskon seperti stimulan yang membuat orang berbelanja.

Diskon musiman seperti ini, menurut Anti (25 tahun) memengaruhi jumlah barang yang dibeli, yang seringkali tidak begitu dibutuhkan dan dibeli secara berlebihan. Ini membuatnya menjadi boros. Menurut Rina (23 Tahun) selama masa pandemi ia merasa bahwa jumlah belanjanya meningkat hingga $50 \%$. Sebelumnya ia tidak terbiasa dengan belanja online, bahkan dalam satu bulannya hanya mencapai dua sampai tiga kali pembelian barang secara online. Namun, karena pandemi 
yang mengharuskan di rumah saja, Rina menghabiskan waktunya untuk membeli produk-produk seperti baju, jilbab dan tas secara lebih intensif. Dalam seminggu ia membeli barang sebanyak tiga kali dengan barang yang serupa dengan merek dan warna yang berbeda. Pengeluarannya pun selama pandemi Covid-19 meningkat tiga kali lipat dibandingkan dengan pengeluaran sebelumnya. Peningkatan jumlah belanjanya ini dipengaruhi juga oleh tawaran barang yang diiklankan dengan diskon harga barang yang semakin meningkat-semakin banyak barang dibeli, semakin banyak diskon-bahkan terkadang disertai dengan gratis ongkos kirim (ongkir).

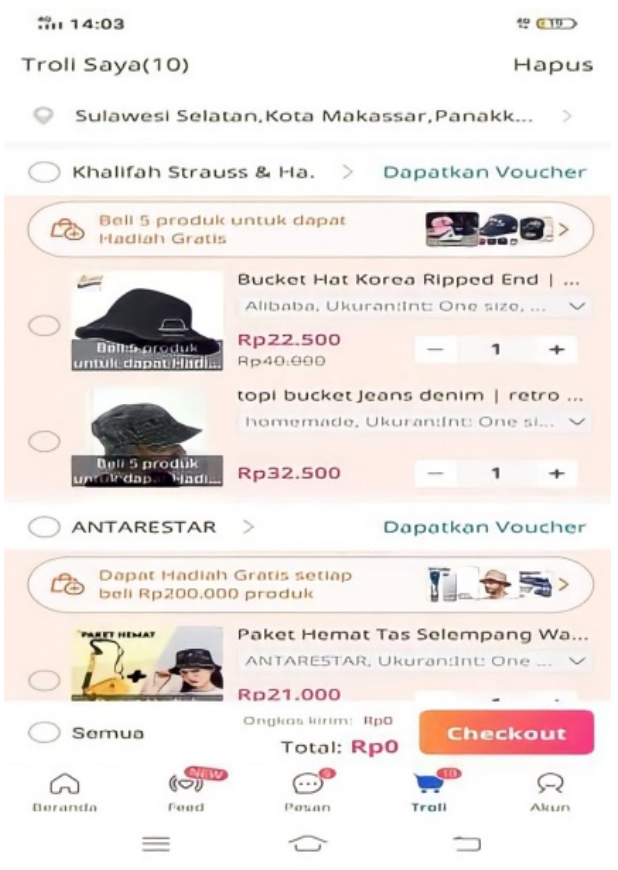

Gambar 2. Potongan harga

Gambar 2 di atas menunjukkan bahwa potongan harga atau diskon yang diberikan oleh aplikasi belanja online seperti ini sangat berpotensi memengaruhi tingkat pembelian barang konsumen, apalagi di masa pandemi Covid-19 banyak pemilik toko online yang tidak segan-segan memberikan potongan harga bahkan cashback sampai 50\%. Banyak konsumen yang membeli barang atau produk hanya karena terpengaruh oleh diskon yang ditawarkan. Ini menunjukkan ambivalensi dari eksistensi tawaran diskon. Di satu sisi, ada frasa yang sering kita dengar, bahwa: "Bukan ibu-ibu namanya jika tidak mencari diskon". Di sisi lain, tawaran diskon memicu keinginan untuk berbelanja lebih banyak.

Barang-barang yang dibeli oleh Tyas (26 tahun), seperti pakaian, alat kecantikan, karena produk ini memiliki diskon yang lebih besar dibandingkan barang lainnya seperti alat kecantikan. Ini menunjukkan bahwa Tyan berbelanja bukan karena kebutuhan akan pakaian atau alat kecantikan, tetapi ia berbelanja karena diskon yang ditawarkan untuk barang tersebut. Namun, menurut Lisna (25 tahun) berbelanja secara online sangat dilematik. Di satu sisi, diskon yang diberikan pada sistem aplikasi membuat dirinya menjadi sangat boros dalam berbelanja. Di sisi lain, 
diskon yang ditawarkan sangat menggiurkan untuk diabaikan. Artinya, diskon membuat Lisna menjadi boros dalam berbelanja. Dalam situasi pendemi Covid-19 dimana waktu lebih banyak dihabiskan di rumah, maka kesempatan untuk browsing toko-toko online dengan berbagai tawaran barang dan harga diskon. Ini biasanya berakhir dengan berbelanja.

Namun, ini berbeda dengan Sardiana (42 tahun) yang dengan tegas menampik argumentasi bahwa diskon memberikan pengaruh yang besar terhadap minat belinya karena diskon tidak menjadi faktor utama yang memengaruhinya dalam berbelanja online. la berbelanja secara online karena memang kondisi yang mengharuskannya melakukan itu. Di saat Covid-19 sedang mewabah, ia ketakutan akan terjangkit. Atas kesadaran sendiri dan diperkuat dengan kebijakan pemerintah untuk membatasi mobilitas, kegiatan-kegiatan yang biasanya dilakukan di luar sebisa mungkin dialihkan secara online, termasuk berbelanja. Barang-barang yang dibeli secara online dapat berupa kebutuhan primer maupun sekunder. Meskipun demikian, ia tidak mengabaikan, bahwa belanja online membuat orang lebih mudah berbelanja dan dengan kemudahan tersebut membuat orang cenderung menjadi konsumtif jika tak dapat mengontrol dirinya.

\section{Kelemahan Belanja Online}

Selain memiliki berbagai kelebihan (kemudahan dan kepraktisan, ketersediaan beragam barang, keamanan dan kenyamanan, dan tawaran diskon) sebagaimana yang dibahas di atas, belanja online juga memiliki kelemahan, yaitu: ketidaksesuaian antara tampilan barang yang dipesan dan kenyataan barang yang diterima; barang tidak dapat langsung diterima karena memerlukan waktu pengiriman; kerentanan akan kerusakan barang dalam proses pengiriman, dan kerentanan terhadap terjadinya penipuan.

Hal utama yang mengecewakan ketika berbelanja secara online adalah ketika barang yang ditampilkan dalam aplikasi berbelanja berbeda dengan barang yang diterima. Selain itu, kadang-kadang barang yang dibeli tidak sesuai dengan gambar yang ada pada aplikasi. Misalnya, ketika Uni (39 tahun) membeli sepatu berwarna biru navy dan berbahan kulit, tapi ketika barang tiba, ternyata warnanya hitam dan berbahan sintetis. Namun, menurutnya hal seperti itu tidak menjadi alasan baginya untuk tidak berbelanja secara online. Belanja online tetap menjadi pilihan nomor satu untuk mengatasi kebiasannya dalam berbelanja dan mencari produk-produk yang diminati mulai dari kebutuhan pribadi maupun kebutuhan untuk keluarganya, terutama di masa pandemi Covid19. Wabah ini membuat orang terkungkung di rumah karena takut tertular Covid-19, dan ia sendiri lebih senang berbelanja dari rumah daripada harus keluar.

Waktu pengiriman menjadi salah satu hal yang cukup membuat jengkel para pembeli barang-barang online. Ada berbagai resiko seperti paket tertahan, paket yang terlambat datang, sampai dengan salah kirim paket. Walaupun pada aplikasi belanja online tersebut terdapat opsi untuk pengiriman paket yang lebih cepat atau ekspres namun hal tersebut akan memakan memakan biaya yang lebih besar daripada pengiriman paket yang biasa atau reguler.

Menurut Uni (39 tahun), jika seseorang berbelanja secara online, maka barang yang dibeli tidak dapat diterima langsung setelahnya. Ini karena pengiriman memerlukan waktu antara satu hingga beberapa hari, tergantung periode pengiriman (misalnya, cepat atau reguler), jarak pengiriman (dekat atau jauh). Namun, terutama di awal pandemi Covid-19, 
pengiriman seringkali terlambat karena banyaknya pembatasan-pembatasan yang harus dipatuhi oleh jasa pengiriman, sehingga pengiriman barang menjadi terlambat.

Berbelanja secara online memerlukan waktu hingga barang diterima karena melalui proses pengiriman, apalagi jika barang yang dibeli adalah barang yang rapuh (fragile). Menurut Nindi (29 tahun), ia pernah memesan barang berupa tripod melalui sebuah aplikasi belanja online. Namun ketika barang datang ia sangat kecewa karena bukan hanya kemasannya yang rusak, tapi juga barang pesanannya ikut rusak. Meskipun ia dapat melakukan komplen kepada toko online tersebut, ini tidak dilakukannya karena ia tidak mau dibuat stres dengan proses yang ribet. la hanya akan berpikir dua kali di masa yang akan datang untuk memesan barang-barang yang fragile. Untuk mengantisipasi kerugian atas kerusakan barang, maka penjual seringkali menawarkan pengiriman dengan asuransi. Namun ongkos kirim plus biaya asuransi cukup mahal, sehingga jarang menjadi pilihan konsumen.

Penipuan sangat potensil terjadi dalam transaksi belanja online. Tidak sedikit korban penipuan belanja online yang mengatasnamakan brand tertentu atau toko online yang menjanjikan barang akan segera dikirim setelah transaksi dilakukan, padahal barang tidak pernah sampai kepada pembelinya. Bahkan ada pembeli yang berniat untuk menipu pemilik toko online dengan cara mengirimkan bukti transfer palsu. Artinya, penipun dapat terjadi dari dua sisi, dari penjual, maupun pembeli.

Tyas (26 tahun) pernah menjadi salah seorang korban penipuan ketika ia memesan sebuah dompet berbahan kulit, namun saat barang tersebut sampai, isi dari paket yang diterimanya adalah sebuah bubble wrap yang dibentuk sedemikian rupa lalu dimasukan ke dalam sebuah boks berukuran kecil. la telah menjadi korban penipuan.

Berbagai kemudahan yang diberikan dalam berbelanja secara online menyebabkan konsumen-jika tidak dapat mengontrol dirisangat berpotensi untuk menjadi konsumtif. Uni (39 tahun), yang merupakan pelanggan tetap dari salah satu aplikasi belanja online terbesar di Indonesia (yaitu Shopee), mengakui adanya perbedaan yang signifikan terhadap jumlah belanjanya sebelum pandemi dan selama pandemi Covid-19.

Jika sebelum pandemi Covid-19, ia lebih sering berbelanja secara langsung di toko/mall, seperti pakaian, tas, assesori yang sebelum pandemi Covid-19 tidak setiap bulan, maka sejak Covid-19 mewabah, kesempatannya untuk berbelanja online semakin intensif. Dalam sebulan ia dapat berbelanja selembar pakaian, maka di masa pandemi Covid-19, pembelian barang ini meningkat secara signifikan, hingga tiga kali lipat per bulan. Seringkali ia membeli produk yang sama dengan warna yang berbeda karena harga diskon yang ditawarkan secara online. Meskipun ia menyadari bahwa ia belanja berlebihan, diskon yang tawarkan sangat menggiurkan, yang membuatnya sulit untuk menahan diri dari godaan berbelanja.

\section{Kesimpulan dan Rekomendasi}

Awal kemunculan Covid-19 menjadi sebuah hal yang menggemparkan sekaligus mengejutkan bagi semua orang di berbagai belahan dunia, termasuk Indonesia, apalagi Indonesia termasuk dalam salah satu negara dengan kasus penularan Covid-19 yang tinggi. Hal ini membuat pemerintah mengeluarkan himbauan Pembatasan Sosial Berskala Besar (PSBB). Himbauan pemerintah untuk melakukan PSBB membuat sebagian besar kegiatan yang dilakukan di luar rumah dialihkan menjadi ke dalam rumah. Perubahan ini membuat banyak 
aspek kehidupan manusia yang berubah, bersekolah, bekerja, beribadah, termasuk berbelanja.

Meskipun berbelanja secara online melalui aplikasi, belanja bukan hal baru bagi masyarakat Indonesia, penggunaannya malah menjadi semakin intensif selama pandemi Covid-19. Hal ini disebabkan oleh perubahan perilaku konsumen yang memenuhi kebutuhan sehari-hari dengan berbelanja online, terutama di masa PSBB. Berbelanja secara online sangat membantu ibu-ibu rumah tangga dalam membeli berbagai kebutuhan, baik kebutuhan primer, maupun kebutuhan sekunder.

Ibu-ibu rumah tangga mempersepsikan belanja online dengan melihat dari sisi yang berbeda: umumnya mereka melihatnya dalam kaitan dengan simplisitas berbelanja; proses transaksi yang menggunakan teknologi maju; hingga berbelanja dengan menggunakan aplikasi belanja online. Adapun alasan kenapa berbelanja online semakin digemari oleh ibu-ibu rumah tangga selama pandemi Covid-19 adalah karena sebagaimana belanja offline, ketersediaan barang juga beraneka ragam, kemudahan dan kepraktisan, keamanan dan kenyamanan, dan tawaran diskon yang menggiurkan.

Selama pandemi Covid-19, belanja secara online semakin intensif. Selain dari kelebihan yang dimilikinya, belanja online juga memiliki kelemahan, yakni seringkali terjadi perbedaan antara barang yang ditawarkan (offered goods) dan barang yang diterima (received goods); barang yang dibeli tidak dapat langsung diterima karena memerlukan proses pengiriman yang lamanya tergantung pada jasa layanan level mana yang digunakan (seperti ekspres, regular, dll.); barang rentan rusak dalam proses pengiriman; dan kerentanan akan penipuan.
Berbelanja online idealnya berfungsi untuk menjadi sarana pemenuhan kebutuhan sehari-hari bagi para ibu rumah tangga dan bukan sebagai pemenuhan nafsu dalam berbelanja. Walaupun berbelanja online memberikan kemudahan dan kenyamanan dalam bertransaksi, akan tetapi hal ini berpotensi menimbulkan perilaku konsumtif, terutama karena di masa pandemi Covid-19. Ibu-ibu rumah tangga lebih banyak menghabiskan waktu di rumah, sehingga lebih leluasa untuk browsing di toko-toko online. Oleh karenanya, konsumen harus mempertimbangkan antara kebutuhan dan keinginan agar dapat mengontrol diri dalam berbelanja karena tidak semua barang yang diinginkan adalah barang yang dibutuhkan. Selain itu, kerawanan akan terjadinya penipuan dalam berbelanja online, maka konsumen tidak saja harus mempertanyakan barang yang akan dibeli sedetail mungkin; selektif dalam memilih toko online; serta harus mengidentifikasi rekam jejak toko online yang dituju.

\section{Daftar Pustaka}

Aeni, E. N. 2019. Pengaruh Onlineshop Terhadap Perilaku Konsumtif Mahasiswa Fakultas Ekonomi Dan Bisnis Islam (FEBI) UIN Walisongo Semarang. Skripsi, Universitas Islam Negeri Walisongo, Semarang.

Anggreini, R. dan Mariyanti, S. 2014. "Hubungan Antara Kontrol Diri Dan Perilaku Konsumtif Mahasiswa Unviversitas Esa Unggul", Jurnal Psikologi: Media IImiah Psikologi, Juni, 12(1):34-42, https://ejurnal.esaunggul.ac.id/index.ph $\mathrm{p} / \mathrm{psiko/article/view/1461, \quad \text {diakses }}$ tanggal 21 Mei 2021.

Astuti, E. D. 2013. "Perilaku Konsumtif dalam Membeli Barang Pada Ibu Rumah 
Tangga di Kota Samarinda", Psikoborneo: Journal Ilmia Psikologi, 1(2):79-83, $\quad$ http://ejournals.unmul.ac.id/index.php/psikone o/article/view/3285, diakses tanggal 15 Januari 2021.

Caroline, D. A. P. 2019. Hubungan Antara Intensitas Pengguna Media Sosial dengan Perilaku Konsumtif Pada Mahasiswi. Skripsi, Universita Muhammadiyah Surakarta, Surakarta.

Harahap, D. A. dan Amanah, D. 2018. "Perilaku Belanja Online Di Indonesia: Studi Kasus", Jurnal Riset Manajemen Sains Indonesia (JRMSI), 9(2):193-213. http://journal.unj.ac.id/unj/index.php/ir msi/article/view/6005/5876, diakses tanggal 9 Desember 2020.

Hasanah, U. 2007. Hubungan Antara Interaksi Teman Sebaya dan Konsep Diri dengan Perilaku Konsumtif Pada Remaja Putri. Skrips, Universitas Muhammadiyah Surakarta, Surakarta.

Hasna. 2019. Fashion Hijab Remaja Di Kecamatan Kelara Kabupaten Jenepotnto (Analisis Respons Ibu Rumah Tangga). Skripsi, Universitas Islam Negeri Alauddin Makassar.

Hermawan, H. 2017. "Sikap Konsumen Terhadap Belanja Online", Wacana, 16(1):136-147, https://docplayer.info/70527896-Sikapkonsumen-terhadap-belanja-onlineherry-hermawan.html, diakses tanggal 15 Desember 2020.

Ismail, A.; Munsi, H.; dan Hans, A. 2019. "Online Social Movement: Adopsi Teknologi Informasi dalam Melakukan Gerakan Sosial di Indonesia", Etnosia: Jurnal
Etnografi Indonesia, 4(1):91-114, https://journal.unhas.ac.id/index.php/e tnosia/article/view/5039, diakses tanggal 27 September 2020.

Kholilah, K. 2008. Perilaku Konsumtif Masyarakat Pengunjung Pasar Kaget di Wisata Belanja Tugu Gajayana Malang. Disertasi, Universitas Islam Negeri Maulana Malik Ibrahim, Malang.

Pemerintah Provinsi Sulawesi Selatan. 2020. Sulsel Tanggap Covid-19. https://covid19.sulselprov.go.id/, diakses tanggal 9 Desember 2020.

Putranto, T. A. 2020. Surat Edaran Menteri Kesehatan Republik Indonesia. www.hukumonline.com/pusatdata, diakses tanggal 27 September 2020.

Rie. $2014 . \quad E$-Commerce, https://bpptik.kominfo.go.id/, diakses tanggal 20 September 2020.

Minanda, A.; Roslan, S.; dan Anggraini, D. 2018. "Perilaku Konsumtif Belanja Online pada Mahasiswa Fakultas IImu Sosial dan IImu Politik Universitas Halu Oleo Kendari", Journal Neo Societal, 3(2):443440, https://www.neliti.com/id/publications/ 246839/perilaku-konsumtif-belanjaonline-pada-mahasiswa-fakultas-ilmusosial-dan-ilmu-p, di akses tanggal 26 Februari 2021.

Sumarni, N.; Faddila, P. S., dan Fauji, R. 2020. “Perilaku Belanja Online Pada Ibu Rumah Tangga Disaat Pandemi Covid19: Studi Kasus Ibu Rumah Tangga Di Anjun Karawang", Kreatif: Jurnal Manajemen dan Bisnis Kreatif, 6(1):1-22 https://journal.ubpkarawang.ac.id/inde 
x.php/Manajemen/article/view/1186,

diakses tanggal 9 Desember 2020.

Thohiroh, A. Q. dan Yuwono, S. 2015. Perilaku Konsumtif Melalui Online Shopping

Fashion Pada Mahasiswi Fakultas

Psikologi Universitas Muhammadiyah

Surakarta. Skripsi, Universitas

Muhammadiyah Surakarta, Surakarta.

WHO. 2019. Coronavirus Disease (Covid-19).

https://www.who.int/emergencies/dise

ases/novel-coronavirus-2019, diakses

tanggal 9 Desember 2020. 